\title{
Peran karakteristik wirausahawan dan kemampuan usaha terhadap keberhasilan usaha di masa pandemi
}

\author{
Susi Widjajani* \\ Program Studi Manajemen, Fakultas Ekonomi, Universitas Muhammadiyah Purworejo \\ Jl. Pahlawan Km 3, Sucenjurutengah, Bayan, Purworejo, 54224, Indonesia \\ wijayanisusi@gmail.com \\ Ridwan Baraba \\ Program Studi Manajemen, Fakultas Ekonomi, Universitas Muhammadiyah Purworejo \\ Jl. Pahlawan Km 3, Sucenjurutengah, Bayan, Purworejo, 54224, Indonesia \\ barabaridwan@gmail.com \\ Rifi Handayani \\ Program Studi Manajemen, Fakultas Ekonomi, Universitas Muhammadiyah Purworejo \\ Jl. Pahlawan Km 3, Sucenjurutengah, Bayan, Purworejo 54224, Indonesia \\ handayanirifi489@gmail.com \\ *Penulis Korespondensi
}

Submitted: Oct 16, 2021; Reviewed: Oct 19, 2021; Accepted: Nov 7, 2021

\begin{abstract}
One of the sectors affected by the coronavirus (Covid-19) pandemic is small business. Its existence, which is essential in supporting the regional economy, is getting worse and requires more efforts to be able to survive during this pandemic. From the demand side, mainly consumption and purchasing power, its performance has decreased, thus disrupting the production process and business success. The role of entrepreneurs is needed to be able to achieve business success. This study aims to examine the role of business ability as a mediating variable on the effect of entrepreneur characteristics on business success. The population of this study is small snack entrepreneurs in Purworejo Regency. Sampling using purposive sampling technique with a total of 100 respondents. This study used a survey method to collect data with the help of a questionnaire. Furthermore, the data is processed using the Hierarchical Regression Analysis method. The results of the study show that the characteristics of entrepreneurs and business abilities partially influence business success. Characteristics of entrepreneurs affect business ability, and business abilities can mediate the influence of entrepreneurial characteristics on business success. The real contribution of the results of this study is expected for snack food entrepreneurs in Purworejo Regency during this pandemic to be able to achieve business success, especially about the characteristics and abilities that small entrepreneurs must possess to survive in a pandemic situation like this.
\end{abstract}

Keywords: business ability; business success; characteristics of entrepreneurs; Covid-19 pandemic

Abstrak: Salah satu sektor yang terdampak dari adanya pandemi virus corona (Covid-19) adalah usaha kecil. Keberadaannya yang penting dalam menyokong perekonomian daerah semakin terpuruk dan membutuhkan upaya lebih agar mampu bertahan di masa pandemi ini. Dari sisi permintaan utamanya konsumsi dan daya beli, kinerjanya mengalami penurunan sehingga mengganggu proses 
produksi dan keberhasilan usaha. Peran pengusaha dibutuhkan agar mampu mencapai keberhasilan usaha. Tujuan dari studi ini adalah untuk menguji peran kemampuan usaha sebagai variabel mediasi pada pengaruh karakteristik wirausahawan terhadap keberhasilan usaha. Populasi dari studi ini adalah pengusaha kecil makanan ringan di Kabupaten Purworejo. Sampel diambil dengan menggunakan teknik purposive sampling dengan jumlah 100 responden. Metode survei digunakan untuk mengambil data dengan bantuan kuesioner. Selanjutnya data diolah dengan menggunakan Hierarchical Regression Analysis. Hasil studi menunjukkan bahwa karakteristik wirausahawan dan kemampuan usaha berpengaruh secara parsial terhadap keberhasilan usaha. Karakteristik wirausahawan berpengaruh terhadap kemampuan usaha, dan kemampuan usaha mampu memediasi pengaruh karakteristik wirausahawan terhadap keberhasilan usaha. Kontribusi nyata dari hasil studi ini diharapkan bagi pengusaha makanan ringan di Kabupaten Purworejo dalam masa pandemi ini untuk dapat mencapai keberhasilan usahanya, terutama berkaitan dengan karakteristik dan kemampuan yang harus dimiliki oleh pengusaha kecil agar mampu bertahan di situasi pandemi seperti ini.

Kata kunci: karakteristik wirausahawan; keberhasilan usaha; kemampuan usaha, pandemi Covid-19

\section{PENDAHULUAN}

Usaha kecil menjadi salah satu sektor di Indonesia yang terdampak pandemi virus corona (COVID19). Bersumber informasi dari Kementrian Koperasi dan UKM memperlihatkan data 1.785 koperasi dan 163.713 pelaku Usaha Mikro Kecil dan Menengah (UMKM) telah terimbas pandemi COVID-19 ini. Koperasi yang terkena imbas COVID-19 kebanyakan bergerak pada bidang kebutuhan seharihari, sedangkan sektor UMKM yang paling terimbas yaitu makanan dan minuman. Tidak hanya itu, industri kreatif dan pertanian ternyata juga terkena dampaknya. Menurunnya penjualan, kurangnya modal, dan terhambatnya distribusi merupakan dampak yang dirasakan oleh para pengusaha kecil (Amri, 2020). Kementerian Koperasi dan UKM telah menerima laporan sekitar 37.000 UMKM yang di masa pandemi ini telah terimbas secara serius. Kondisi yang dilaporkan adalah terjadinya penurunan penjualan sebesar $56 \%$, permasalahan terkait aspek pembiayaan sebesar $22 \%$, masalah terkait dengan distribusi barang sebesar $15 \%$, dan kesulitan dalam pemenuhan bahan baku mentah sebanyak 4\% (Crismawan, 2020). Kinerja konsumsi dan daya beli yang merupakan bagian dari sisi permintaan juga mengalami penurunan yang berakibat pada proses produksi dan keberhasilan usaha.

Keberhasilan usaha pada hakikatnya merupakan keberhasilan dari bisnis menggapai tujuannya. Untuk dapat mencapai tujuan tersebut, dibutuhkan adanya kemauan dan kemampuan dari para pengusaha kecil untuk tetap menjalankan usahanya agar berhasil. Penelitian terdahulu menunjukkan bahwa beberapa hal yang memengaruhi berhasil tidaknya suatu usaha adalah karakteristik wirausahawan dan kemampuan usaha. Hasil studi Abdulwahab \& Al-Damen (2015) menunjukkan terdapat pengaruh karakteristik wirausahawan terhadap keberhasilan usaha kecil pada Medical Instruments Supplies Organizations di Jordan. Namun penelitian Bustan (2016) menemukan tidak terdapat pengaruh antara karakteristik wirausaha terhadap keberhasilan bisnis pada usaha kecil pengolahan pangan di Kota Palembang. Sedangkan Wingwon et al. (2011) mengatakan bahwa karakteristik wirausahawan memiliki pengaruh tidak langsung terhadap keberhasilan usaha kecil di wilayah utara Thailand.

Di sisi lain, keberhasilan usaha juga dipengaruhi oleh kemampuan usaha (Fithriani \& Marditama, 2020). Pada penelitian Gemina et al. (2016), kemampuan usaha berada pada posisi memediasi hubungan antara motivasi terhadap keberhasilan usaha pada industri kecil menengah makanan ringan di Priangan Timur-Indonesia. Atas dasar hasil-hasil penelitian terdahulu tersebut, peneliti berupaya untuk memandang dari sudut pandang yang lain, yaitu dengan memadukan antara variabel karakteristik wirausahawan dan keberhasilan usaha, serta meletakkan kemampuan usaha sebagai variabel yang memediasi keduanya. Hal ini perlu dilakukan karena berdasar hasil review dari Mitchelmore \& Rowley (2010) yang merekomendasikan bahwa kemampuan usaha membutuhkan penelitian lebih lanjut terkait dengan keberhasilan usaha dalam praktik. Oleh karena itu, tujuan dari penelitian ini adalah untuk menguji pengaruh karakteristik wirausahawan terhadap keberhasilan usaha yang dimediasi oleh kemampuan usaha. 
Keberhasilan usaha dapat ditinjau dari sudut pandang kualitatif dan kuantitatif (Assauri, 2016). Dari sisi kualitatif, keberhasilan usaha dapat dilihat dari hal-hal non finansial, yang meliputi kecepatan pengembangan produk, reputasi, maupun paten. Sementara dari sisi kuantitatif, biasanya berkaitan dengan keuangan atau finansial. Kemudian, seorang wiarusahawan dapat mengukur keberhasilan usaha melalui bukti kinerja yang sudah diraih, yaitu bertumbuhnya perusahaan yang dikelola. Keberhasilan usaha yang akan dicapai sangat tergantung pada banyak hal, antara lain yaitu dari karakteristik wirausahawan dan juga kemampuan usaha yang dimiliki oleh pengusahanya.

Uraian terkait dengan variabel-variabel yang memengaruhi keberhasilan usaha, dapat digambarkan dalam suatu model penelitian sebagaimana Gambar 1 berikut:

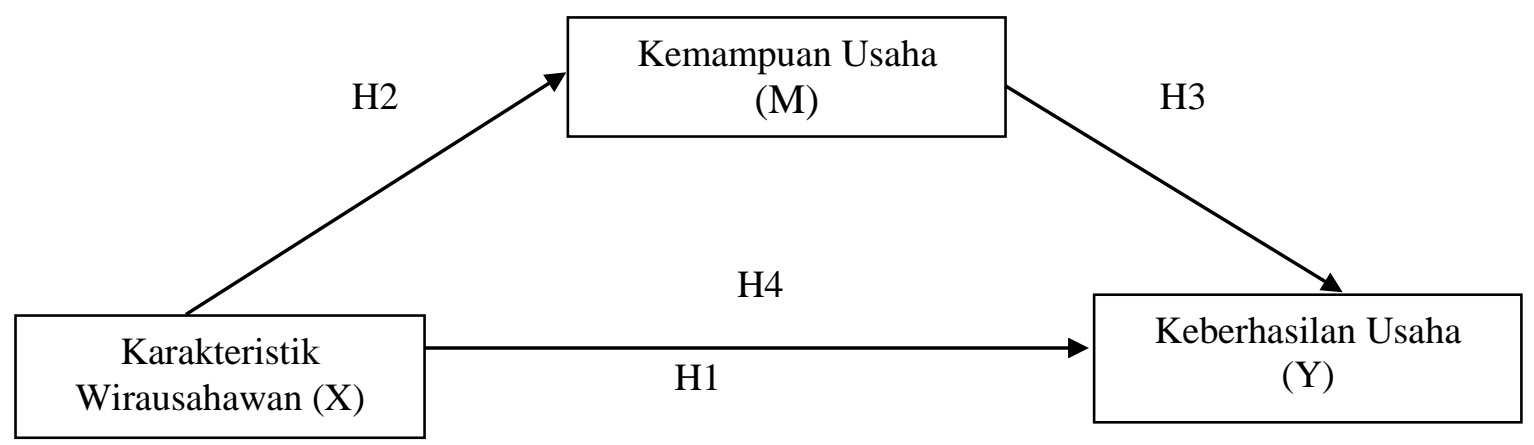

Gambar 1. Model penelitian

Sumber: Hasil analisis peneliti (2021)

Menurut Abdulwahab \& Al-Damen (2015), karakteristik wirausahawan yang memiliki karakter untuk selalu mempunyai need for achievement (kebutuhan akan pencapaian), self-confidence (kepercayaan diri), proactiveness (sikap proaktif), independency (kemandirian), responsibility (tanggung jawab), dan risk-taking propensity (kecenderungan berani mengambil resiko), akan mempunyai peluang yang lebih besar untuk berhasil dalam menjalankan usahanya. Seorang wirausahawan yang mampu menunjukkan keberhasilan usaha bisnisnya akan lebih mempunyai karakter yang kuat dalam bekerja, dan karakter wirausaha yang kurang kuat cenderung akan menurun keberhasilan usahanya. Hal ini diperkuat dengan hasil penelitian-penelitian sebelumnya yang mengatakan bahwa ada pengaruh yang positif antara karakteristik wirausahawan terhadap keberhasilan usaha (Hakim \& Prajanti, 2019; Ishaq \& Abbass, 2020; Islam et al., 2011; Machmud \& Hidayat, 2020; Senjoyo, 2018). Atas dasar hal-hal tersebut, selanjutnya dirumuskan hipotesis sebagai berikut:

H1: Karakteristik wirausahawan memiliki pengaruh positif terhadap keberhasilan usaha.

Kemampuan usaha merupakan kumpulan kapasitas tertentu yang sesuai untuk memacu keberhasilan (Chaifetz, 2010). Pencapaian keberhasilan usaha dapat dilakukan melalui peningkatan faktor-faktor yang mendukungnya yang merupakan mekanisme dari kemampuan berwirausaha. Suatu kesempatan akan diubah menjadi hasil positif jika seorang wirausahawan mampu mengelola sumber daya internal dan sumber daya ekternalnya (Mahadalle \& Kaplan, 2017). Karakter pribadi, yang merupakan bagian dari sumber daya internal, mewujudkan suatu kapasitas yang harus dikembangkan. Seseorang yang berkarakter kuat umumnya menjadi pribadi yang tidak begitu saja tunduk oleh sekelompok realitas yang terjadi. Begitupun bagi individu yang berkarakter kurang kuat, cenderung akan patuh pada berbagai kondisi yang ada tanpa bisa mengendalikannya. Oleh karena itu, karakter dari seorang wirausahawan akan mampu memengaruhi kemampuan dalam menjalankan usahanya. Hal ini senada dengan hasil penelitian yang telah dilakukan (Fazlurrahman et al., 2017). Untuk itu, hipotesis yang dapat dibangun berdasar hal tersebut adalah:

H2: Karakteristik wirausahawan memiliki pengaruh positif terhadap kemampuan usaha.

Kemampuan usaha industri kecil akan mendukung keberhasilan usaha dan pertumbuhan dalam pembangunan ekonomi suatu negara (Mitchelmore \& Rowley, 2010). Banyak faktor yang dapat memengaruhi keberhasilan seseorang dalam melakukan wirausaha, di antaranya yaitu faktor kemauan dan kemampuan, kerja keras dan tekad yang kuat, serta adanya kesempatan dan peluang. Faktor internal dan faktor eksternal juga menjadi bagian dari keberhasilan usaha. Kemampuan, kemauan, 
serta kelemahan menjadi bagian dari faktor internal. Sementara itu kesempatan dan peluang menjadi bagian dari faktor eksternal diri pelaku usaha. Kemampuan, kemauan, serta pengetahuan wajib dimiliki oleh seorang wirausahawan agar berhasil. Jika ada kemauan tapi tidak diikuti kemampuan dan pengetahuan, maka akan sulit untuk menjadi seorang wirausahawan yang sukses. Hasil penelitian yang dilakukan oleh para peneliti sebelumnya (Fithriani \& Marditama, 2020; Hakim \& Prajanti, 2019; Laurens \& Kohardinata, 2020; Saputri et al., 2018; Tehseen \& Ramayah, 2015) mendukung uraian di atas yang menyatakan bahwa kemampuan usaha memiliki pengaruh positif dan signifikan terhadap keberhasilan usaha. Selanjutnya rumusan hipotesis yang dibangun adalah:

H3: Kemampuan usaha memiliki pengaruh positif terhadap keberhasilan usaha.

Kemampuan usaha dipandang penting untuk pertumbuhan dan keberhasilan usaha (Mitchelmore \& Rowley, 2010). Peningkatan kemampuan berwirausaha dilakukan dalam rangka untuk mewujudkan keunggulan kompetitif guna meraih keberhasilan usaha. Selanjutnya, kemampuan yang dimiliki oleh wirausahawan dalam mengelola usahanya akan sangat tergantung pada karakteristik individu yang dimilikinya. Karakteristik individu akan memengaruhi keberhasilan usaha, tergantung sejauh mana kemampuan yang dimiliki oleh pengusahanya. Sedangkan studi dari Gemina et al. (2016) memposisikan kemampuan usaha sebagai variabel mediasi yang berhubungan dengan keberhasilan usaha. Berdasarkan uraian tersebut, rumusan hipotesis yang diajukan sebagai berikut:

H4: Kemampuan usaha memediasi pengaruh karakteristik wirausahawan terhadap keberhasilan usaha.

\section{METODE}

Penelitian ini mengambil populasi pengusaha kecil makanan ringan yang ada di wilayah Kabupaten Purworejo sebanyak 100 orang responden. Sampel diambil dengan menggunakan teknik purposive sampling dengan kriteria pengusaha yang telah menjalankan usahanya minimal 1 tahun, dan memiliki karyawan paling sedikit 1 orang.

Variabel yang digunakan dalam penelitian ini melibatkan tiga variabel, yakni variabel independen adalah karakteristik wirausahawan, variabel dependen keberhasilan usaha, serta variabel mediasi adalah kemampuan usaha. Karakteristik wirausahawan adalah perwujudan gagasan inovatif yang diterapkan pada dunia usaha yang terkait dengan watak, sikap, tabiat, ciri khusus, perilaku, serta tindakan seseorang. Adapun indikator yang digunakan untuk mengukur karakteristik wirausahawan menurut Abdulwahab \& Al-Damen (2015) adalah need for achievement (kebutuhan akan pencapaian), self-confidence (kepercayaan diri), proactiveness (sikap proaktif), independency (kemandirian), responsibility (tanggung jawab), dan risk-taking propensity (kecenderungan mengambil resiko). Keberhasilan usaha merupakan pencapaian tujuan dari kegiatan bisnis tersebut, yang ditandai dengan diperolehnya laba yang menjadi tujuan utamanya. Indikator-indikator keberhasilan usaha menurut Irawan \& Mulyadi (2016) adalah laba, produktivitas, efisiensi, daya saing, kompetensi, etika usaha, dan terbangunnya citra baik. Selanjutnya, yang dimaksud dengan kemampuan usaha adalah bakat sejak lahir atau bisa juga berupa hasil dari proses belajar yang digunakan untuk menyelesaikan suatu usaha. Indikator dari variabel kemampuan usaha diadopsi dari Suryana (2016), yakni: self knowledge, imagination, practical knowledge, search skill, forseight, computation skill, dan communication skill. Skala Likert digunakan untuk mengukur data yang diperoleh secara kuantitatif. Skala Likert berupa angka 1-5 yang mana angka 1 menunjukkan sangat tidak setuju dengan pernyataan penelitian, selanjutnya angka lima menunjukkan sangat setuju dengan pernyataan yang disampaikan kepada responden.

Penelitian ini merupakan penelitian survei yang menggunakan bantuan kuesioner untuk mengumpulkan data. Data yang diperoleh selanjutnya diolah dan dianalisis dengan menggunakan teknik Hierarchical Regression Analysis untuk menguji hipotesis. Langkah-langkah dalam menguji hipotesis mengacu pada pengujian peran mediator Baron \& Kenny (1986), yang dikutip oleh Hayes \& Rockwood (2017) sebagai berikut: pertama, membuat persamaan regresi karakteristik wirausahawan (X) terhadap keberhasilan usaha (Y), kedua, membuat persamaan regresi karakteristik wirausahawan (X) terhadap kemampuan usaha (M), serta ketiga, membuat persamaan regresi karakteristik wirausahawan $(\mathrm{X})$ dan kemampuan usaha $(\mathrm{M})$ terhadap keberhasilan usaha $(\mathrm{Y})$. Analisis regresi ini akan menghasilkan dua nilai estimasi prediktor dari $\mathrm{M}$ dan $\mathrm{X}$, yaitu prediksi $\mathrm{M}$ terhadap $\mathrm{Y}$ dan prediksi X terhadap Y. Selanjutnya, mengambil kesimpulan dengan cara membandingkan hasil 
langkah pertama dengan hasil langkah ketiga. Dalam mengambil kesimpulan, maka kemungkinan yang akan diperoleh adalah: perfect mediation (jika hasil langkah pertama signifikan dan hasil langkah ketiga tidak signifikan) atau berupa partial mediation (jika hasil langkah pertama signifikan, dan hasil langkah ketiga tetap signifikan, meskipun koefisien regresi mengalami penurunan).

\section{HASIL DAN PEMBAHASAN}

\subsection{Hasil penelitian}

Suatu butir pernyataan dikatakan valid bila memiliki angka koefisien pearson correlation melebihi 0.3. Uji validitas instrumen menunjukkan angka koefisien pearson correlation seluruh indikator dari variabel karakteristik wirausahawan, kemampuan usaha, dan keberhasilan usaha dengan nilai pearson correlation lebih dari 0.3 dan seluruhnya memiliki nilai positif. Oleh karena itu, dapat diambil kesimpulan bahwa seluruh indikator yang dimasukkan dalam pengujian tersebut adalah valid. Maknanya bahwa seluruh item pernyataan yang ada dalam kuesioner penelitian bisa mengukur secara tepat variabel penelitiannya. Sedangkan berdasarkan hasil uji reliabilitas, memperlihatkan angka Cronbach's Alpha > 0.7, yang maknanya bahwa item-item pernyataan dari variabel karakteristik wirausahawan, kemampuan usaha, dan keberhasilan usaha yang dipakai dalam studi ini, bisa menunjukkan hasil yang konsisten.

Atas dasar hasil dari pengujian normalitas data yang memakai uji One-Sample KolmogorovSmirnov Test, menunjukkan bahwa data yang diujikan dalam studi ini untuk variabel karakteristik wirausahawan, kemampuan usaha, dan keberhasilan usaha adalah berdistribusi normal. Kondisi ini diperlihatkan melalui angka Asymp. Sig (2-tailed) sebesar 0.169 (>0.05), yang artinya nilai dari residual yang terstandarisasi berada pada posisi yang menyebar secara normal. Selanjutnya, uji multikolinearitas digunakan untuk mengkaji matriks hubungan antar variabel independen dan perhitungan nilai tolerance dan variance inflation factor (VIF). Berdasarkan hasil uji tersebut, nilai $V I F$ variabel karakteristik wirausahawan dan kemampuan usaha sebesar $1.141(<10)$, oleh karena itu dapat dikatakan bahwa model regresi yang digunakan dalam penelitian ini tidak memiliki indikasi multikolinearitas. Sedangkan untuk menguji heteroskedastisitas memakai scatterplot. Dari grafik plot, menunjukkan pola yang tidak jelas, selain itu titik-titik berada pada posisi atas dan bawah angka 0 di sumbu Y, sehingga heterokedastisitas tidak terjadi.

Selanjutnya, hipotesis akan diuji dengan menggunakan langkah-langkah Hierarchical Regression Analysis, dan diperoleh hasil sebagai berikut:

Langkah pertama dipakai untuk menganalisis hipotesis pertama $\left(\mathrm{H}_{1}\right)$, yaitu karakteristik wirausahawan berpengaruh positif terhadap keberhasilan usaha. Hasil uji regresi ditunjukkan pada Tabel 1 berikut:

Tabel 1. Hasil analisis langkah 1

\begin{tabular}{lcc}
\hline Keterangan & Koefisien Regresi & $p$ value \\
\hline $\mathrm{X} \rightarrow \mathrm{Y}$ & 0.37 & 0.001 \\
$\mathrm{R}$ Square & & 0.113 \\
\hline
\end{tabular}

Sumber: Data diolah (2021)

Pada Tabel 1 menunjukkan bahwa nilai koefisien regresi karakteristik wirausahawan (X) terhadap keberhasilan usaha $(\mathrm{Y})$ sebesar 0.337 , sehingga diperoleh persamaan regresi sebagai berikut $\mathrm{Y}=$ $0.337 X$. Selanjutnya, diperoleh nilai $p$ value sebesar 0.001 yang membuktikan adanya pengaruh signifikan variabel karakteristik wirausahawan terhadap keberhasilan usaha dalam persamaan regresi, karena lebih kecil dari 0.005 . Hal ini berarti bahwa hipotesis pertama dalam penelitian ini dapat diterima.

Langkah kedua digunakan untuk menganalisis hipotesis kedua $\left(\mathrm{H}_{2}\right)$, yaitu karakteristik wirausahawan berpengaruh positif terhadap kemampuan usaha. Tabel 2 memperlihatkan hasil analisis regresi berikutnya di bawah ini. 
Tabel 2. Hasil analisis langkah 2

\begin{tabular}{lcc}
\hline Keterangan & Koefisien Regresi & $p$ value \\
\hline $\mathrm{X} \rightarrow \mathrm{M}$ & 0.352 & 0.000 \\
$\mathrm{R}$ Square & & 0.124 \\
\hline
\end{tabular}

Sumber: Data diolah (2021)

Berdasarkan hasil analisis data pada Tabel 2, nilai koefisien regresi karakteristik wirausahawan (X) terhadap kemampuan usaha (M) sebesar 0.352. Sehingga, diperoleh hasil persamaan regresi sebagai berikut: $\mathrm{M}=0.352 \mathrm{X}$. Nilai $p$ value sebesar 0.000 , yang mana nilai tersebut menunjukkan signifikansi variabel karakteristik wirausahawan terhadap kemampuan usaha dalam persamaan regresi karena lebih kecil dari 0.05 . Artinya bahwa hipotesis kedua dalam penelitian ini, yaitu karakteristik wirausahawan berpengaruh positif terhadap kemampuan usaha, dapat diterima.

Langkah 3 digunakan untuk menganalisis hipotesis ketiga $\left(\mathrm{H}_{3}\right)$, yaitu kemampuan usaha $(\mathrm{M})$ berpengaruh positif terhadap keberhasilan usaha (Y). Selain itu, langkah 3 dilakukan dengan tetap memasukkan variabel kemampuan usaha dalam pengujian hubungan karakteristik wirausahawan terhadap keberhasilan usaha.

Tabel 3. Hubungan variabel independen terhadap mediasi

\begin{tabular}{lcc}
\hline Keterangan & Koefisien Regresi & $p$ value \\
\hline $\mathrm{M} \rightarrow \mathrm{Y}$ & 0.262 & 0.009 \\
$\mathrm{X}+\mathrm{M} \rightarrow \mathrm{Y}$ & 0.245 & 0.015 \\
$\mathrm{R}$ Square & & 0.174 \\
\hline
\end{tabular}

Sumber: Data diolah (2021)

Tabel 3 memperlihatkan nilai koefisien regresi kemampuan usaha (M) terhadap keberhasilan usaha (Y) sebesar 0,262 dan didapatkan persamaan regresi $\mathrm{Y}=0.262 \mathrm{M}$. Nilai $p$ value sebesar 0.009 , yang menunjukkan adanya pengaruh signifikan karena nilainya lebih kecil dari 0.05 . Hal ini menunjukkan bahwa hipotesis ketiga, yaitu kemampuan usaha berpengaruh positif terhadap keberhasilan usaha, didukung.

Langkah 4 digunakan untuk menganalisis hipotesis keempat $\left(\mathrm{H}_{4}\right)$, yaitu kemampuan usaha memediasi pengaruh karakteristik wirausahawan terhadap keberhasilan usaha. Hasil analisis regresi langkah 4 ditunjukkan pada Tabel 4 berikut.

Tabel 4. Hubungan variabel independen terhadap mediasi

\begin{tabular}{lcc}
\hline Keterangan & Koefisien Regresi & $p$ value \\
\hline $\mathrm{X} \rightarrow \mathrm{Y}$ & 0.337 & 0.001 \\
$\mathrm{X}+\mathrm{M} \rightarrow \mathrm{Y}$ & 0.245 & 0.015 \\
\hline
\end{tabular}

Sumber: Data diolah (2021)

Atas dasar hasil perbandingan nilai signifikansi pada Tabel 4, diketahui bahwa nilai signifikansi pengaruh karakteristik wirausahawan (X) terhadap keberhasilan usaha (Y) sebesar 0.001 (signifikan). Sedangkan, setelah memasukkan variabel kemampuan usaha $(\mathrm{M})$ ke dalam pengaruh karakteristik wirausahawan (X) terhadap keberhasilan usaha (Y), nilai signifikansi sebesar 0.015 (tetap signifikan). Maknanya bahwa hipotesis keempat dalam penelitian ini diterima, yaitu kemampuan usaha memediasi pengaruh karakteristik wirausahawan terhadap keberhasilan usaha. Dilihat dari nilai koefisien regresi, karakteristik wirausahawan (X) terhadap keberhasilan usaha (Y) mengalami penurunan setelah diregresikan bersama dengan variabel kemampuan usaha $(\mathrm{M})$, artinya pengaruh mediasi yang terjadi adalah partial mediation.

Selain itu, peran mediator juga dapat dianalisis dari signifikansi efek tidak langsungnya. Besarnya efek tidak langsung serta uji signifikansi peran mediator dapat dilakukan dengan menggunakan Sobel Test. Uji Sobel Test adalah alat uji yang dipakai untuk mengetahui apakah variabel mediasi yang dipilih dalam model regresi mampu memediasi hubungan variabel independen dan variabel dependen. 
Data yang dipakai dalam Sobel Test adalah koefesien regresi $(a, b)$ serta standard error of estimation dari $a$ dan $b$. Berdasarkan hasil perhitungan Sobel Test, diperoleh nilai 2.011 yang mana lebih besar dari nilai tabel (1.96) pada tingkat signifikansi 5\%, yang artinya variabel kemampuan usaha mampu memediasi pengaruh karakteristik wirausahawan terhadap keberhasilan usaha.

\subsection{Pembahasan}

Hipotesis pertama, yang dirumuskan dalam studi ini, adalah karakteristik wirausahawan berpengaruh positif terhadap keberhasilan usaha, dinyatakan didukung. Nilai koefisien regresi positif memperlihatkan bahwa semakin kuat karakteristik wirausahawan makanan ringan yang berada di wilayah Kabupaten Purworejo, akan memengaruhi tingkat keberhasilan usahanya. Karakteristik yang dimiliki oleh para pengusaha makanan ringan di Kabupaten Purworejo menjadi hal yang penting dalam menjalankan usaha bisnis, karena hal tersebut dapat memengaruhi keberhasilan usahanya di masa pandemi Covid-19 ini. Wirausahawan makanan ringan di Kabupaten Purworejo, yang memiliki karakteristik kuat dikarenakan memiliki kebutuhan untuk pencapaian, rasa percaya diri, sikap proaktif, memiliki kemandirian, memiliki rasa tanggung jawab, dan berani menghadapi resiko yang baik, cenderung akan mampu bertahan di masa pandemi ini. Pada saat pandemi di mana daya beli masyarakat menurun, para pengusaha makanan ringan tersebut tetap memiliki kemauan yang keras dan gigih untuk berhasil dalam usahanya. Memiliki keyakinan bahwa mereka mampu untuk menjalankan usahanya meski dalam situasi pandemi. Para pengusaha ini berusaha untuk selalu menciptakan pelayanan yang terbaik dan memahami kebutuhan konsumen. Mereka juga mampu bertindak secara mandiri dan tidak bergantung terhadap orang lain maupun bantuan dari pemerintah. Bertanggung jawab dan berani mengambil resiko adalah ciri khas para pengusaha ini. Hasil penelitian ini sesuai dengan yang dikemukakan oleh Li \& Jia (2015) bahwa tidak semua wirausahawan berhasil dalam usahanya, dan dibutuhkan karakteristik wirausahawan yang khusus agar memungkinkan untuk sukses. Karakteristik wirausahawan merupakan sifat dan keterampilan pribadi yang menjadi kompetensi dari wirausahawan yang dibutuhkan untuk keberhasilan usaha (Bouazza et al., 2015). Kecuali itu juga memperkuat hasil penelitian sebelumnya yang dilakukan (Hakim \& Prajanti, 2019; Ishaq \& Abbass, 2020; Islam et al., 2011; Machmud \& Hidayat, 2020; Senjoyo, 2018) yang mengemukakan adanya pengaruh positif antara karakteristik wirausahawan terhadap keberhasilan usaha. Namun tidak mendukung penelitian Bustan (2016) yang mengatakan tidak ada pengaruh karakteristik wirausahawan terhadap keberhasilan usaha.

Selanjutnya hipotesis kedua, adalah karakteristik wirausahawan berpengaruh positif terhadap kemampuan usaha, dinyatakan dapat didukung. Angka koefisien regresi yang positif menunjukkan bahwa semakin kuat karakteristik wirausahawan makanan ringan yang berada di wilayah Kabupaten Purworejo, akan memengaruhi tingkat kemampuan usahanya. Berdasar hasil penelitian, wirausahawan makanan ringan di Kabupaten Purworejo ternyata telah mempunyai pemahaman yang memadai terkait usaha yang akan dilakukan atau ditekuninya. Di masa pandemi ini mereka tetap memiliki imajinasi, ide, dan perseptif dalam mengelola usahanya serta tidak menggantungkan keberhasilan yang telah dicapai pada masa sebelumnya. Meskipun pengetahuan praktis yang mereka miliki masih terbatas, seperti pemahaman secara teknik, desain, proses produksi, pencatatan keuangan, manajemen dan pemasaran, tetapi para pengusaha ini memiliki pandangan jauh ke depan. Mereka memiliki kemampuan menghitung dan memperkirakan kondisi yang akan terjadi ke depannya. Melalui pengetahuan untuk berkomunikasi, bergaul, dan berhubungan dengan orang lain, para pengusaha ini terus berjuang untuk mampu bertahan di masa pandemi ini. Kemampuan usaha yang mereka miliki ini dikarenakan para pengusaha memiliki karakteristik wirausahawan yang kuat. Kuat tidaknya karakteristik wirausahawan akan memengaruhi wirausahawan ketika harus menjalankan fungsi mikronya sebagai inovator, yaitu kemampuan usaha dalam melakukan transformasi yang berkesinambungan terhadap kegiatan usaha sesuai dengan kemajuan dan perkembangan zaman (Kristanto, 2011). Penelitian sebelumnya juga mengungkapkan masalah yang serupa bahwa karakteristik wirausahawan memiliki pengaruh positif dan signifikan terhadap kemampuan berwirausaha (Fazlurrahman et al., 2017).

Hipotesis ketiga, yaitu kemampuan usaha berpengaruh positif terhadap keberhasilan usaha, dinyatakan didukung. Nilai koefisien regresi yang positif menggambarkan semakin baik kemampuan usaha pengusaha makanan ringan yang berada di wilayah Kabupaten Purworejo, akan meningkatkan tingkat keberhasilan usahanya. Pada masa wabah Covid-19 sekarang ini, tidaklah mudah bagi para 
pengusaha makanan ringan di Kabupaten Purworejo ini untuk mengukur tingkat keberhasilan usahanya. Tapi setidaknya, jika dilihat dari pendapatan yang diterima masih cukup baik meskipun ada penurunan. Penurunan pendapatan ini disebabkan karena daya beli masyarakat menurun sehingga jumlah barang yang diproduksi pun juga menurun. Namun, dalam situasi pandemi saat ini justru pengusaha makanan ringan mampu meningkatkan efisiensi penggunaan faktor produksinya. Dengan kondisi yang serba terbatas, pengusaha makanan ringan justru mampu berkreasi dan meningkatkan kompetensinya sehingga mampu meningkatkan daya saingnya di pasaran. Meski tingkat persaingan cukup ketat, para pengusaha makanan ringan ini tetap memperhatikan etika dalam berusaha agar tetap terbangun citra yang baik dalam usahanya. Untuk mencapai hal-hal seperti tersebut di atas bukanlah hal mudah, tetapi dibutuhkan adanya kemampuan usaha dalam mengelola usahanya. Hasil penelitian ini menguatkan teori yang disampaikan oleh Mitchelmore \& Rowley (2010) bahwa kemampuan usaha industri kecil akan mendukung keberhasilan usaha dan pertumbuhan dalam pembangunan ekonomi suatu negara. Penelitian sebelumnya juga mengatakan hal yang serupa, yaitu kemampuan usaha akan berpengaruh terhadap keberhasilan usaha (Fithriani \& Marditama, 2020; Hakim \& Prajanti, 2019; Laurens \& Kohardinata, 2020; Saputri et al., 2018; Tehseen \& Ramayah, 2015).

Hasil uji mediasi hipotesis keempat (H4), yaitu kemampuan usaha memediasi pengaruh karakteristik wirausahawan terhadap keberhasilan usaha pengusaha makanan ringan di Kabupaten Purworejo, dapat diterima. Diterimanya hipotesis keempat pada penelitian ini menunjukkan bahwa karakteristik wirausahawan pengusaha makanan ringan yang kuat akan meningkatkan keberhasilan usahanya, jika diikuti oleh kemampuan usaha yang baik. Demikian juga sebaliknya jika karakteristik wirausahawannya lemah, maka kemungkinan untuk meraih keberhasilan usahanya kecil, apalagi jika diikuti dengan kemampuan usaha yang rendah. Dalam teori kewirausahaan dikatakan bahwa kesuksesan atau keberhasilan usaha akan diperoleh jika wirausahawan memiliki karakter yang kuat serta kemampuan kreatif dan inovatif dalam mencari peluang usaha (Hamdani, 2019). Penelitian sebelumya yang dilakukan juga memposisikan kemampuan usaha sebagai variabel mediasi yang berhubungan dengan keberhasilan usaha (Gemina et al., 2016).

\section{SIMPULAN DAN SARAN}

Kesimpulan dari hasil studi ini adalah bahwa kemampuan usaha mampu memediasi pengaruh karakteristik wirausahawan terhadap keberhasilan usaha secara parsial, artinya ada atau tidak ada kemampuan usaha, maka karakteristik wirausahawan tetap memiliki pengaruh terhadap keberhasilan usaha. Antara karakteristik wirausahawan dan kemampuan usaha yang dimiliki oleh para pengusaha kecil makanan ringan di Kabupaten Purworejo secara parsial memiliki pengaruh signifikan terhadap keberhasilan usaha. Hasil studi ini diharapkan dapat memberikan kontribusi nyata bagi pengusaha makanan ringan di Kabupaten Purworejo dalam mencapai keberhasilan usaha di masa pandemi ini, terutama berkaitan dengan karakteristik dan kemampuan yang harus dimiliki oleh pengusaha kecil agar mampu bertahan di situasi yang seperti ini. Oleh karena itu, implikasi bagi pengusaha makanan ringan yang ada di Kabupaten Purworejo adalah untuk meningkatkan kesadaran akan pentingnya karakteristik dalam berwirausaha maupun kemampuan usaha yang harus dimiliki oleh seorang wirausahawan agar usahanya berhasil.

Penelitian ini tidak lepas dari adanya keterbatasan, yaitu yang pertama jumlah responden relatif sedikit dan hanya melibatkan pengusaha kecil makanan ringan saja, sehingga untuk penelitian selanjutnya bisa diperluas tidak hanya usaha makanan ringan tetapi juga usaha lain dengan jumlah yang lebih banyak agar lebih mudah mengeneralisasikannya. Selain itu, juga hanya mengukur usaha kecil saja, sehingga peneliti selanjutnya bisa memasukkan usaha menengah dan besar agar lebih bervariasi. Saran untuk penelitian yang akan datang bisa mempertimbangkan faktor demografi sebagai faktor yang memengaruhi keberhasilan usaha. Meskipun karakteristik dan kemampuan usaha berpengaruh terhadap keberhasilan usaha, tetapi jika melihat nilai $\mathrm{R}$ Square yang hanya sebesar $17.4 \%$, memperlihatkan bahwa faktor yang lebih besar memengaruhi keberhasilan usaha adalah faktor-faktor lain di luar karakteristik wirausahawan dan kemampuan usaha. Bagi peneliti selanjutnya untuk menggunakan variabel seperti motivasi berwirausaha, modal, penggunaan teknologi, maupun strategi berwirausaha yang digunakan sebagai anteseden bagi keberhasilan usaha. 


\section{REFERENSI}

Abdulwahab, M. H., \& Al-Damen, R. A. (2015). The impact of entrepreneurs' characteristics on small business success at medical instruments supplies organizations in Jordan. International Journal of Business and Social Science, 6(8), 164-175. www.ijbssnet.com

Amri, A. (2020). Dampak covid-19 terhadap UMKM di Indonesia. Jurnal Brand, 2(1), 123-130. https://core.ac.uk/download/pdf/326501743.pdf

Assauri, S. (2016). Strategic manajement sustainable competitive advantages. Rajawali Pers

Bouazza, A. B., Ardjouman, D., \& Abada, O. (2015). Establishing the factors affecting the growth of small and medium-sized enterprises in Algeria. American International Journal of Social Science, $4(2)$

$101-115$.

https://citeseerx.ist.psu.edu/viewdoc/download?doi=10.1.1.1084.1132\&rep=rep1\&type=pdf

Bustan, J. (2016). Pengaruh karakteristik wirausaha, orientasi pembelajaran dan orientasi kewirausahaan terhadap keberhasilan usaha. Jurnal Manajemen dan Bisnis Sriwijaya, 14(1), 2942. https://doi.org/https://doi.org/10.29259/jmbs.v14i1.8844

Chaifetz, R. A. (2010). Two Must-haves for growth: Entrepreneurial spirit and focus on core competencies. American Journal of Business, 25(1), 12-23. https://www.proquest.com/docview/214179384

Crismawan, A. B. (2020). Pengaruh covid19 terhadap UMKM di Indonesia. Genial. http://genial.id/read-news/pengaruh-covid19-terhadap-umkm-di-indonesia

Fazlurrahman, I. R., Fariyanti, A., \& Suharno, S. (2017). Pengaruh karakteristik pribadi dan dimensi sosial terhadap kemampuan wirausaha perempuan. Forum Agribisnis, 6(2), 179-196. https://doi.org/10.29244/fagb.6.2.179-196

Fithriani, M., \& Marditama, T. (2020). Pengaruh kemampuan entrepreneur dalam mengembangkan bisnis terhadap keberhasilan usaha. Prospek-Jurnal Program Studi Pendidikan Ekonomi, 1(2), 41-48. http://jurnal.unsil.ac.id/index.php/prospek/article/view/2949/1675

Gemina, D., Silaningsih, E., \& Yuningsih, E. (2016). Pengaruh motivasi usaha terhadap keberhasilan usaha dengan kemampuan usaha sebagai variabel mediasi pada industri kecil menengah makanan ringan Priangan Timur-Indonesia. Jurnal Manajemen Teknologi, 15(3), 297-323. https://doi.org/10.12695/jmt.2016.15.3.6

Hakim, L., \& Prajanti, S. D. W. (2019). Pengaruh karakteristik wirausaha, kemampuan manajerial, dan tenaga kerja terhadap keberhasilan usaha IKM. Economic Education Analysis, 8(2), 698-712. https://doi.org/10.15294/eeaj.v8i2.31510

Hamdani, S. R. (2019). Kewirausahaan. Uwais Inspirasi Indonesia

Hayes, A. F., \& Rockwood, N. J. (2017). Regression-based statistical mediation and moderation analysis in clinical research: Observations, recommendations, and implementation. Behaviour Research and Therapy, 98, 39-57. https://doi.org/10.1016/j.brat.2016.11.001

Irawan, A., \& Mulyadi, H. (2016). Pengaruh keterampilan wirausaha terhadap keberhasilan usaha. Journal of Businness Management and Enterpreneurship Education, 1(1), 213-223. https://doi.org/https://doi.org/10.17509/jbme.v1i1.2290

Ishaq, F., \& Abbass, A. (2020). Characteristics of Islamic entrepreneurship: Success of small and medium enterprises (SMEs) in Pakistan. Business \& Social Science Journal Characteristics, 5(2), 1-15. https://doi.org/:10.13140/RG.2.2.20908.90242

Islam, M. A., Khan. M. A., Obaidullah, A. Z. M., \& Alam, S. N. (2011). Effect of entrepreneur and firm characteristics on the business success of small and medium enterprises (SMEs) in Bangladesh. International Journal of Business and Management, 6(3), 288-299. https://doi.org/10.5539/ijbm.v6n3p289

Kristanto, R. H. (2011). Kewirausahaan (entrepreneurship): Pendekatan manajemen dan praktik. Graha Ilmu

Laurens, J., \& Kohardinata, C. (2020). Pengaruh motivasi dan kemampuan usaha terhadap keberhasilan usaha startup makanan di Surabaya. PERFORMA: Jurnal Manajemen dan Start-Up Bisnis, 5(3), 223-232. https://doi.org/https://doi.org/10.37715/jp.v5i3.1771

Li, X., \& Jia, Y. (2015). Characteristics influence for entrepreneurship behavior ability. Proceedings of the International Conference on Education, Management, Commerce and Society, 17(Emcs), 614-619. https://doi.org/10.2991/emcs-15.2015.123

Machmud, A., \& Hidayat, Y. M. (2020). Characteristics of Islamic entrepreneurship and the business 
success of SMEs in Indonesia. Journal of Entrepreneurship Education, 23(2), 1-10. https://www.abacademies.org/articles/characteristics-of-islamic-entrepreneurship-and-thebusiness-success-of-smes-in-indonesia-9048.html

Mahadalle, A., \& Kaplan, B. (2017). Entrepreneurial characteristics and competencies as determinants corporate performance: A Study on Small Entreprises in Mogadishu, Somalia. International $\begin{array}{lllll}\text { Journal of Research } & \text {-GRANTHAALAYAH, } & \text { 5(5), } & \text { 243-254. }\end{array}$ https://doi.org/https://doi.org/10.29121/granthaalayah.v5.i5.2017.1856

Mitchelmore, S., \& Rowley, J. (2010). Entrepreneurial competencies: A literature review and development agenda. International Journal of Entrepreneurial Behaviour \& Research, 16(2), 92-111. https://doi.org/10.1108/13552551011026995

Saputri, R., Marwan, U., \& Kurniawati, T. (2018). Faktor-faktor yang mempengaruhi keberhasilan usaha penerima bantuan KUBE Kanagarian Lakitan Tengah Kecamatan Lengayang Kabupaten Pesisir Selatan. EcoGen, 1(4), 915-924. https://doi.org/https://doi.org/10.24036/jmpe.v1i4.5671

Senjoyo, I. K. S. (2018). Pengaruh karakteristik wirausahawan terhadap kesuksesan UMKM di Kota Surabaya. Agora, 6(2), 1-6. http://publication.petra.ac.id/index.php/manajemenbisnis/article/view/7748

Suryana. (2016). Kewirausahaan: Kiat dan proses menuju sukses. Salemba Empat

Tehseen, S., \& Ramayah, T. (2015). Entrepreneurial competencies and smes business success: The contingent role of external integration. Mediterranean Journal of Social Sciences, 6(1), 50-61. https://doi.org/10.5901/mjss.2015.v6n1p50

Wingwon, B., Lertpachin, C., \& Laolalit, B. (2011). The affect of environment, personality traits, entrepreneurship, social status, wealth and motivation toward the success of small business in the Northern Region, Thailand. The International Conference on Sustainable Community Development, January, 144-154. https://cscd.kku.ac.th/uploads/proceeding/080911_103123.pdf 